\title{
特別寄稿 「Neurosonologyの道」
}

\section{超音波定量的血流量測定装置による 総頸動脈血流量の測定 計測精度と生理学的变動}

\author{
古平 国泰，和田 高士，真家 健一，古幡 博* \\ 東京慈恵会医科大学第四内科学教室 \\ *同医用エンジニアリング研究室
}

\section{Measurement of Common Carotid Flow Volume by Ultrasonic Quantitative Flow Measurement System - Accuracy and physiological variation-}

\author{
Kuniyasu KODAIRA M.D., Takashi WADA M.D., Ken-ichi MAIE M.D., Hiroshi FURUHATA Ph.D., M.D.* \\ The 4th Department of Internal Medicine, *Medical Engineering Laboratory, \\ The Jikei University School of Medicine.
}

\begin{abstract}
Ultrasonic quantitative flow measurement system (QFM) was developed to measure an absolute flow volume of common carotid artery (CCA) noninvasively as one of the cerebral circulation tests. It is verified from the model experiment that the output is independent of the depth of vessel and the angle between beam and flow. Moreover, the accuracy is confirmed by the comparison with the electromagnetic flow meter; the error is less than $\pm 7 \%$. However, it is required for accurate and reproducible measurements to handle the probe properly to detect an adequate amplitude of wall echo and to set the gate position at the vessel inner surface echo. The following clinical results have been obtained: 1) There is no significant difference in CCA flow volume between right and left sides. 2) The mean value of male/female is 1.058 . 3)The CCA flow volume is decreased with age: $8.98 \mathrm{~m} l / \mathrm{s}$ in $20 \mathrm{~s}$ and $8.03 \mathrm{~m} l / \mathrm{s}$ in 70s. 4) Body position: The rapid standing from supine position decreases the CCA fiow volume; the ratio ranged from $-3.3 \%$ to $-22.2 \%$. 5) It is suspected that the CCA flow is independent of the blood pressure. 6) CCA fiow volume in sleeping stage decreases $10 \%$ in REM and $20 \%$ in non-REM.
\end{abstract}

Key words: ultrasonics, flowmeters, carotid arteries, cerebral arteries.

筆者らは脳循環系の非侵襲的かつ定量的な検査法確立 を目的として，1978年総頸動脈血流量の絶対値計測可能 な超音波定量的血流量測定装置 (ultrasonic quantitative flow measurement system : QFM) を開発した。その後 本装置は現在国外で約 20 , 国内では 50 以上の施設で臨
床, 研究に利用されている.

装置の原理についてはすでに他誌でも充分解説してい るので, ここでは, 主に精度, 計測時の留意点, 正常血 流量および生理的変動につき述べる。

干 105 東京都港区西新橋 3-25-8 東京慈恵会医科大学第四内科学教室

Kuniyasu KODAIRA: The 4th Department of Internal Medicine, The Jikei University School of Medicine, 3-25-8 Nishishinbashi

Minatoku Tokyo 105 Japan. 


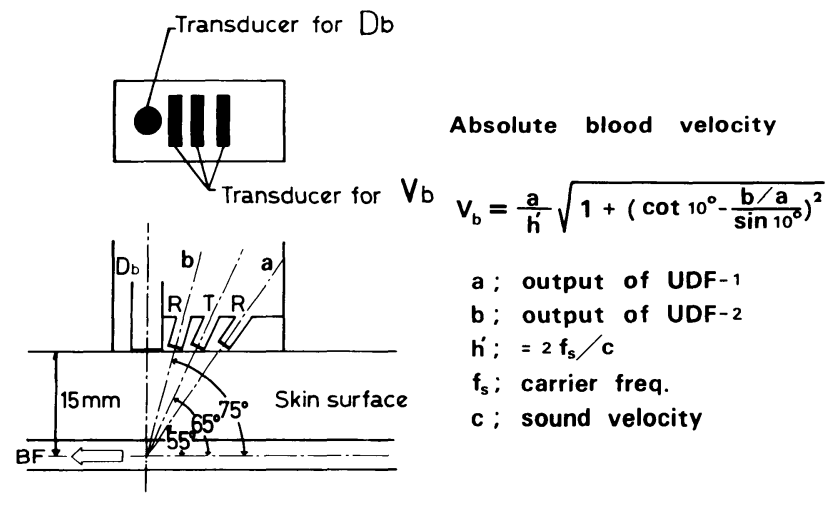

Fig. 1 Diagram of transducer array in the probe and equation to calculate the absolute velocity.

\section{1. 超音波定是的血流专測定装置(QFM)の原理と 同時計測用プローブ(1)-4,12)}

本装置の原理は血管径と血流速を同時計測し，血管断 面積と血流速の積から血流量を定量的に算出するもので ある. 血管断面積は細い超音波パルス $(7.5 \mathrm{MHz})$ を体 表から測定血管に照射し，血管の前・後壁からの反射パ ルスエコーにゲートをかけ，その拍動をエコートラッキ ング法により追跡し，血管径を測定して算出する．絶対 血流速は，筆者らが考案した入射角に依存しない 1 送波 2 受波方式の連続波ドプラ法 $(5 \mathrm{MHz})$ により計測する.

Fig.1 左は, 本装置のプローブの模式図である. $14 \times$ $25 \times 25 \mathrm{~mm}$ の小型プローブに 4 枚の振動子が組み込ま れている. 血管径計測用には直径 $3 \mathrm{~mm}$ の丸型振動子 1 枚が，プローブ表面に対して垂直に取り付けてある。血 流計測用には $2 \times 10 \mathrm{~mm}$ の角型振動子を 3 枚用い, これ らはプローブ表面に対し 75 度， 65 度，55 度に取り付け てあり, 中央が送波用, 両側が受波用である。この受波 用振動子よりの出力 $\mathrm{a}, \mathrm{b}$ からの Fig.1 右の計算式にて絶 対血流速を算出する. ドプラ信号処理には, 方向指示型 ゼロクロスカウンタ方式を用いている。 これら 4 枚の振 動子の音場は総頸動脈の走行を考え深さ $15 \mathrm{~mm}$ にて交 叉するよう配置配列してある。本装置の計測項目は，血 流量の平均, 最大, 最小値, 血流速の平均, 最大, 最小 值, 血管径の平均, 最大, 最小值, 拍動幅および各波形 と心拍数である.

\section{2. 計测精度}

血流モデル実験装置を作製し, 本装置の深度依存性, 照射角依存性および流量測定精度を検討した結果を示す。

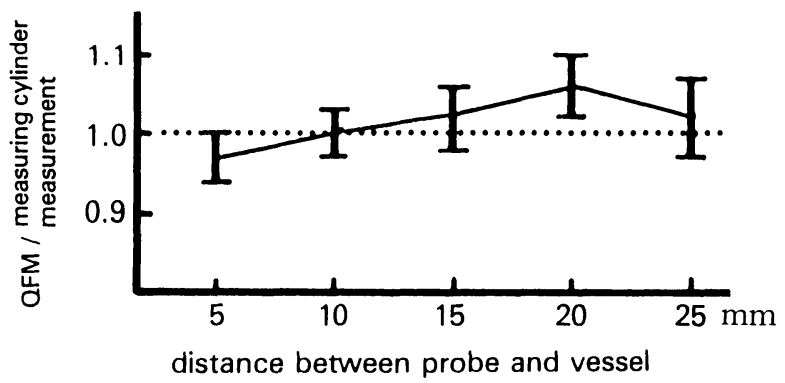

Fig. 2 Effect of distance between probe and vessel on measuring accuracy of QFM (A deviation within 10\% at the depth of $5 \mathrm{~mm}$ to $25 \mathrm{~mm}$ ).

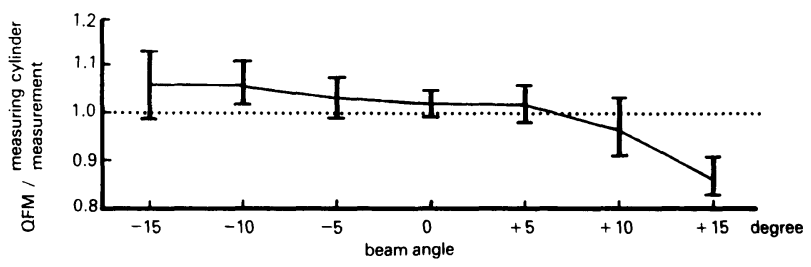

Fig. 3 Effect of beam angle on measuring accuracy of QFM (Only 10\% deviation within the range from -15 to +10 degrees of beam angle).

\section{2-1 深度依存性について}

モデルは, 内径 $5 \mathrm{~mm}$ のアクリル製リジェットチュー ブを水槽内に沈め，人血を流すもので，流量は定常流を メスシリンダで測定している.プローブをモデル血管直 上で $5,10,15,20,25 \mathrm{~mm}$ と移動し計測した結果を Fig. 2 に示す。縦軸はメスシリンダによる計測值に対する 誤差率である５～25 mm まで誤差率は $\pm 10 \%(1 \mathrm{SD}$ ) 以内で深度依存性はないと考えられる。

\section{2-2 照射角依存性}

同様な方法でプローブをモデル血管直上 $15 \mathrm{~mm}$ にセ ットし, プローブを血管走行に対し, 土15 度まで傾け計 測した結果を示す. Fig.3 は, 照射角変化に伴う計測誤差 を示したもので，横軸はプローブ表面の血管に対する角 度である. +15 度で誤差が大きくなるが, $-15 〜+10$ 度 まで誤差率は土10\%（1 SD）以内である，角度補正をし ない従来のドプラ法では計算上土10 度で約 $\pm 30 \%$ の誤 差を生ずる. 前述のごとくQFM では血流速と血管径を 同時計測するが，血管径計測時にゲートセットする前・ 後壁エコーはプローブが垂直位から 5 度傾斜すると約半 減し, 10 度では特に後壁エコーはほとんど検出不可とな る5). このため前・後壁エコーが検出されている状態での 計測では角度依存による誤差は $10 \%$ 以内で問題ないと 結論づけられる。 


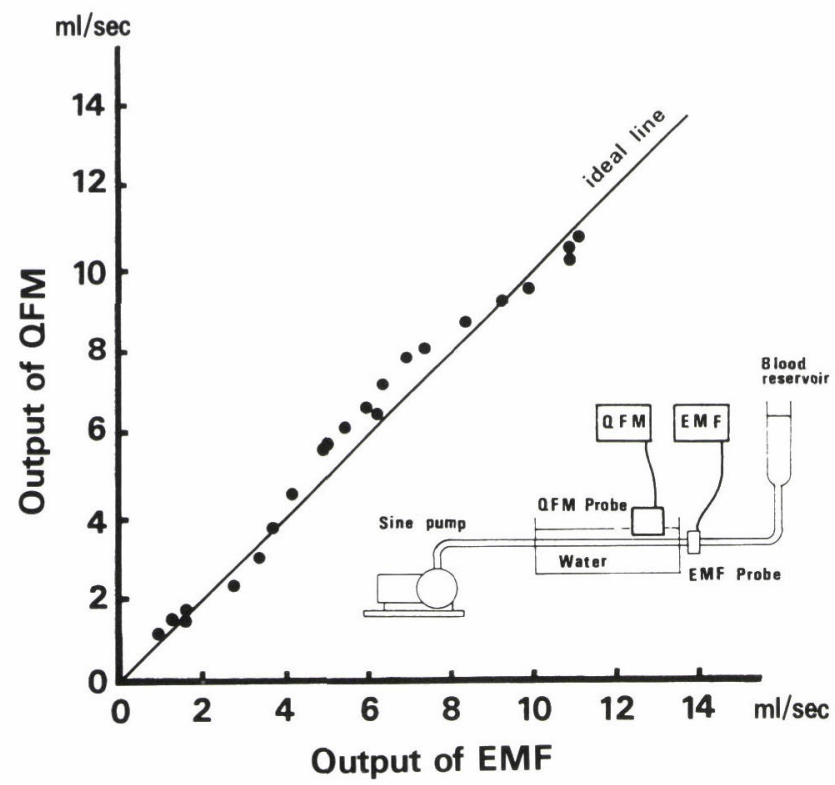

Fig. 4 Comparison of mean blood flow volume measured with between QFM and electromagnetic flowmeter $(E M F)$ in model experiment (A deviation within $7 \%$ in the flow volume of 1 to $12 \mathrm{ml} / \mathrm{sec}$ ).

\section{2-3 流量測定精度}

Fig.4 右下のような実験モデルを組み, 人血を用い種久 な流量について電磁流量計 (electromagnetic flow meter: EMF) と比較し本装置の測定值を検討している. プローブはモデル血管直上 $15 \mathrm{~mm}$ に水平にセットして いる. Fig.4の縦軸は本装置による計測值, 横軸が EMF による計測值である。 $1 \mathrm{~m} \ell / \mathrm{s}$ から $12 \mathrm{~m} \ell / \mathrm{s}$ までほぼ直線 性を示し，計測䛊差は土7\%以下である。

Müller はシリコンチューブに Sephadex solution を 流し，モデル実験を行なっている。これによると拍動流 下では $800 \mathrm{~m} \ell / \mathrm{min}$ まではやや過大評価傾问（200～300 $\mathrm{m} \ell / \mathrm{min}$ では+ $6.5 \%$, 平均 $+2 \%), 800 \mathrm{ml} / \mathrm{min}$ 以上では やや過小評価傾向にあったが, 定常流, 拍動流ともに $p<$ 0.001 の危険率をもって実流量と極めて直線的な相関を 示したと報告している67).

Uematsu は in vivoの計測において生理的拍動流で $\mathrm{QFM}$ と電磁流量計との相関は $r=0.94$ と報告してい $3^{8) 9)}$.

その他現在実用化されている血流量測定装置である MAVIS (multi-channel artery and vein imaging system）との比較などの報告もあるが，現状では総頸動脈血. 流量計測に関してはQFM が一番信頼おける装置である と考えられる.

本装置の測定可能範囲は, 流量 $1 \sim 64 \mathrm{m \ell} / \mathrm{s}$, 流速 5

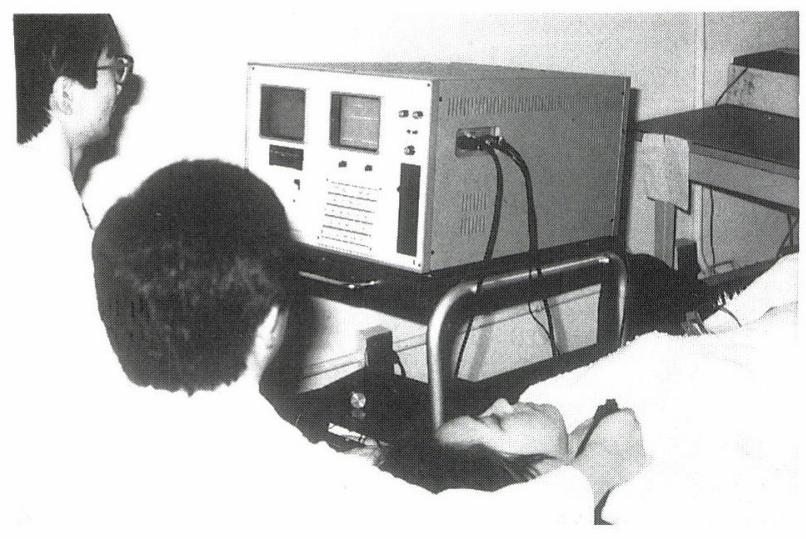

Fig. 5 A scene of actual measurement by QFM.

$\sim 128 \mathrm{~cm} / \mathrm{s}$, 血管径 $2 \sim 15 \mathrm{~mm}$, 血管墚度 $8 \sim 25 \mathrm{~mm}$ で ある。

\section{3. 臨床計測}

\section{3-1 高精度計測のために}

Fig.5 は, QFM の計測風景である。計測手順および計 測上の注意点を説明する.

状況設定：一般計測は仰臥位にて行なう。この場合計 測前に被検者を少なくとも5 分間は安静に保つことが必 要である。特に初回計測では，検査に対する不安感もあ り，また急いで来院した場合状態が落ち着くにも多少時 間がかかる、筆者らはこの間にQFM 計測の説明をした り，症状や既往歴等を収集したりして被検者をりラック スさせるように努めている。また室温は，できれば一年 を通じて一定であることが望ましい.

プローブ操作：解剖学的に総頸動脈が走行していると 推定される部位にエコーゼリーを介しプローブを軽く皮 膚に圧着させる。この時注意することは, プローブを強 く押さえないことである。なぜなら, 被検者の苦痛, 血 管の変形等のため, 安定した計測ができなくなるからで ある、次に，モニタとドプラ音を聴取しながら計測に最 適なポイントを探索する。モニタには，ドプラ波形（千 ヤンネル a，チャンネルb)，血管壁拍動波形，心電网を 表示する波形監視用モニタ (Fig.6 A)，トラッキングゲー 卜をかけるための壁偏位モ二タ（Fig.6 B）がある。まず 波形監視用モ二夕を見ながら血流音が大きく聴取できチ ヤンネルaおよびチャンネルbの血流速波形が同じよ うな波形になるようにプローブを設定する。チャンネル a , b の波形が相似であるということは, 前述の血流計測 用振動子 3 枚がすべて血管を覆つた位置にあることを示 し，こ机は正しい平均流速計測に非常に重要なことであ 


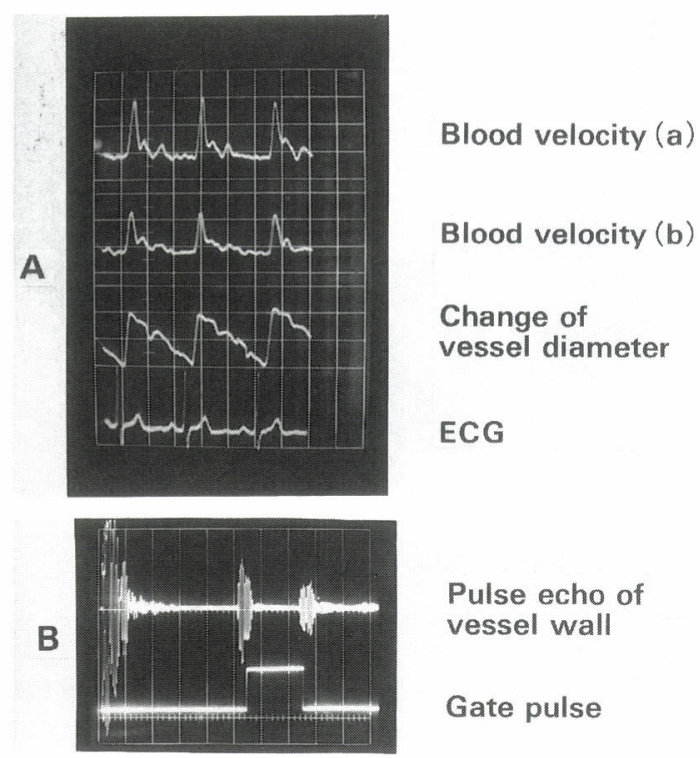

Fig. 6 Monitor display.

A: to verify the stability of the measuring waveforms. B: to set gate pulse at the reflected pulse echo from the inner veesel wall.

る。次に壁偏位モニタをみながら血管徍測定を行なう. 壁偏位モ二タには，生体からの反射パルスエコーが表示 され，左端から皮膚面からの反射エコー，血管前壁の外・ 内側エコー，後壁の内・外側エコーである。このとき血 管壁からのエコーが明瞭になるように再度プローブの位 置を微調整する。即ち, 前・後壁エコーが明瞭に出て血 流情報も最良な点を探すわけである。プローブと血管の 位置関係は，基本的には平行かつ直上になった時に最も よい波形が得られる。この状態で血管径測定，血管壁拍 動を得るため前壁の内側と後壁の内側エコーにゲートを 合わせる (Fig.6 B)。この時ゲートを正確に設定しないと 測定誤差の原因となる.QFM は, 前述のごとく血管径か ら求める断面積に平均血流速を乗じて絶対血流量を計算 する。そのため血管内径の設定が不十分であると実際の 流量より計算上多くなりがちになる. 故に前壁, 後壁と も内側エコーに正確にゲートをかけなくてはならない. プローブの設定ができ, $\mathrm{a}, \mathrm{b}$ の血流速波形, 壁拍動波形が 安定していることを確認（Fig.6 A) したら計測に入る.

計測：筆者らの方法としては, 0 心拍を加算平均して 1 波形とし，計 5 回測定する。そのなかで血流量の最大， 最小の 2 測定を除き残りの 3 回の測定結果をさらに加算 平均し被検者の測定波形, 血流量とする. 加算平均を行 なうのは，波形のバラツキを排除するためである。計測 時, 期外収縮などで 10 心拍とれない時は， 5 心拍で測定

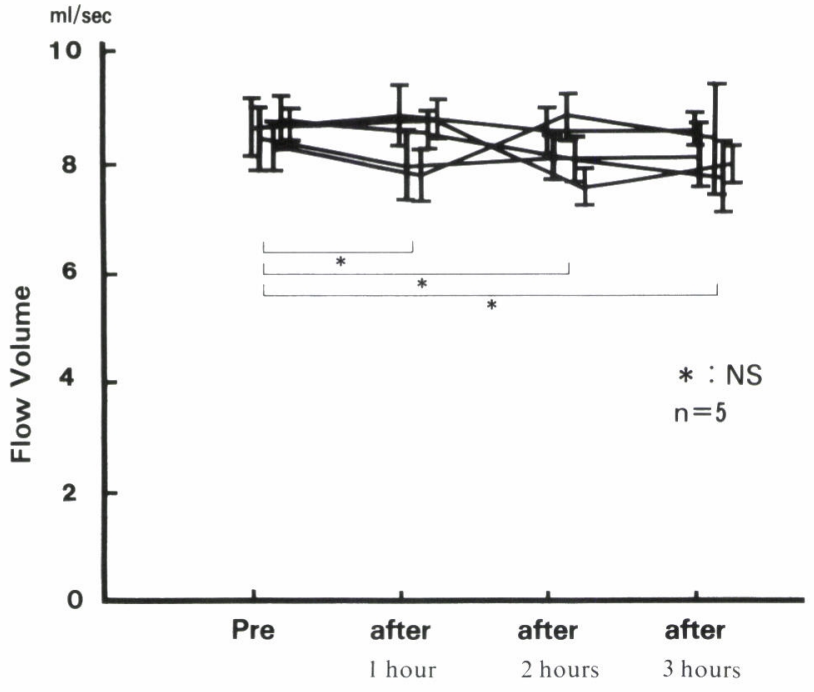

Fig. 7 Variability and reproducibility of the carotid blood flow volume on 5 normal subjects.

するまた心房細動では，後述するが正確な計測はでき ない.

\section{3-2 計測値の再現性}

血流量測定装置としての有用性には，その精度ととも に再現性の有無も重要な要素である.

本装置の再現性を検討するため, 健常青年 5 名につい て以下の計測を行なっている。1名につき安静臥位で 10 回の計測をし，これを前值とし，同様の計測を $1,2,3$ 時間 後に行なった結果を Fig.7 に示す. 各例の 10 回の平均值 と分散で，平均值を実線で結んである。各例とも前值に 対し 1，2，3 時間後の䛊差は土15\%(1 SD) 以内である.

Uematsu も健常者 5 例の左右につき 3 週間に渡る再 現性を検討しており，同一計測時の変動は土3.8\%（1 $\mathrm{SD})$, 他計測間での変動は土10.6\% (1 SD) で, これは 正常血流量範囲内での変動であったとしている ${ }^{8)}$. 再現 性としては充分と考えられる。

\section{4. 正常総頸動脈血流量}

\section{4-1 総頸動脈血流量の加齢による変化}

Fig.8 は，若・高齢者の計測例である。両者には最高血 流量に著明な差異が認められ，波形の違いも顕著である. 若齢者では，収縮期の前半に鋭いピークを持ち，ほとん どの血流が流れるが，高龄者ではこのピークが減高し， 収縮期全体で血流を保つようになる。波形の解析も各個 人の加齢変化や動脈硬化性変化進行の程度を計るのに重 要であるが, 別の機会に譲り，ここでは血流量の正常值 につき述べる。 

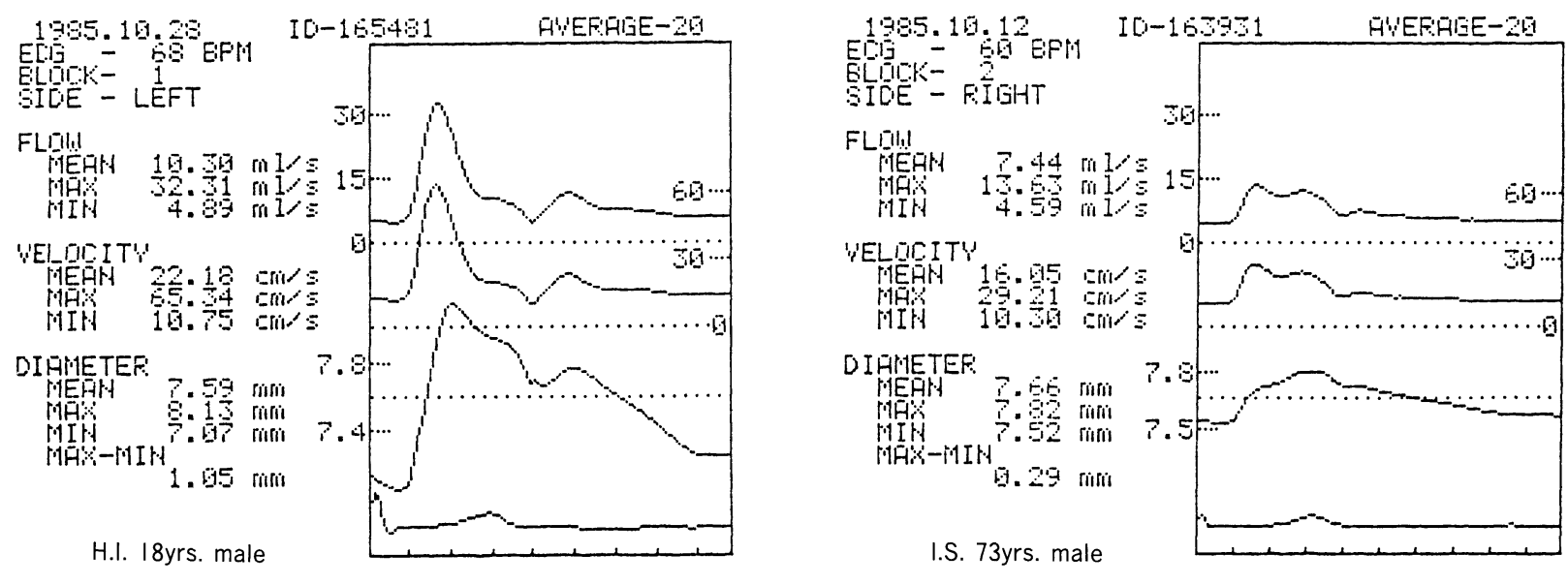

Fig. 8 Typical blood flow information of common carotid artery in young and old subjects.

Fig.9 は, 血流量值の加齢による変化を示したもので 20 歳代から 70 歳代まで, 各年代 25 例左右の平均值と分 散である. 最高, 平均, 最低流量とも有意な左右差は認 められない，最高流量は，加齢により著明に低下し， 20 歳代約 $26.5 \mathrm{~m} \ell / \mathrm{s}$ が 70 歳代約 $16.5 \mathrm{~m} \ell / \mathrm{s}$ となる。これは

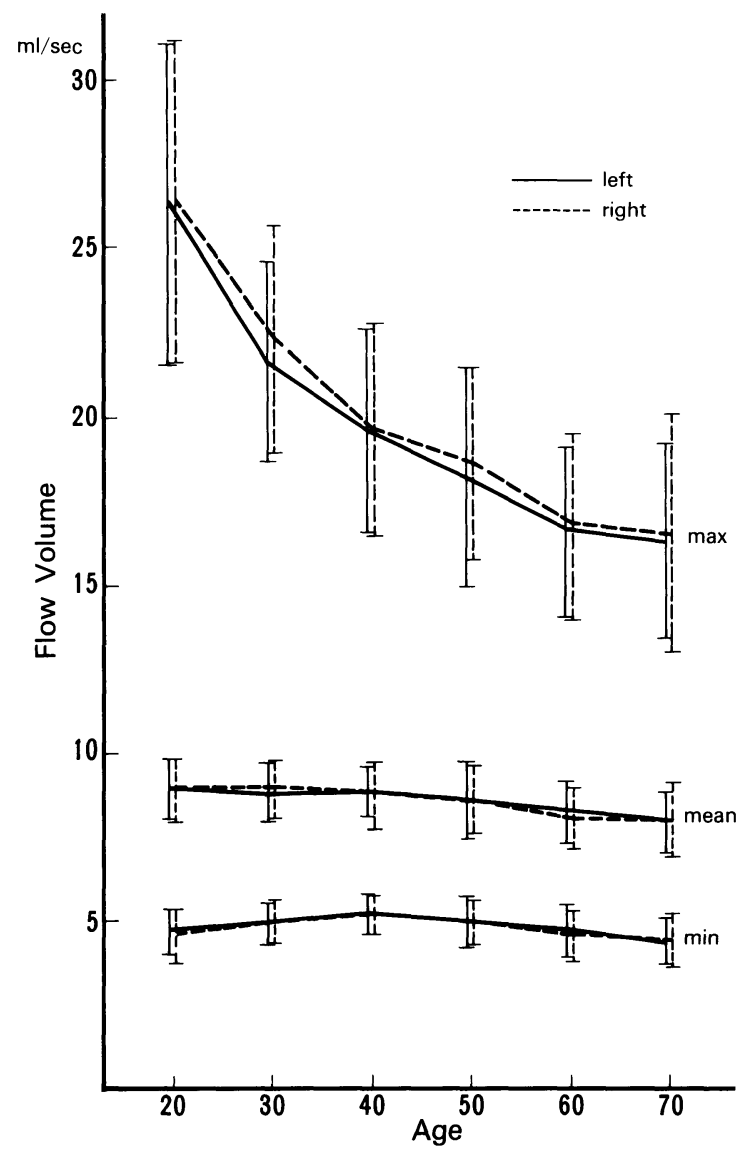

Fig. 9 Change in common carotid blood flow volume with aging $(n=25)$.
加齢に伴う末梢血管抵抗の増大を強く反映した結果と考 えられる.しかし平均血流量は加齢によっても比較的良 く保たれ, 70 歳代でも 20 歳代に比べその低下は約 $1 \mathrm{m \ell} /$ $\mathrm{s}$ 程度である。

QFM 計測による健康成人の総頸動脈血流量の報告は いくつかあるが，加齢変化については同様に若干の低下 の報告が多い.

新生児については Uematsu が報告しており 32 例，平 均年齢 $2.9 \pm 2.3$ 日について左側平均 $1.6 \pm 0.46 \mathrm{ml} / \mathrm{s}$, 右側平均 $1.6 \pm 0.30 \mathrm{~m} \ell / \mathrm{s}$ としている ${ }^{8)}$.ここでも左右

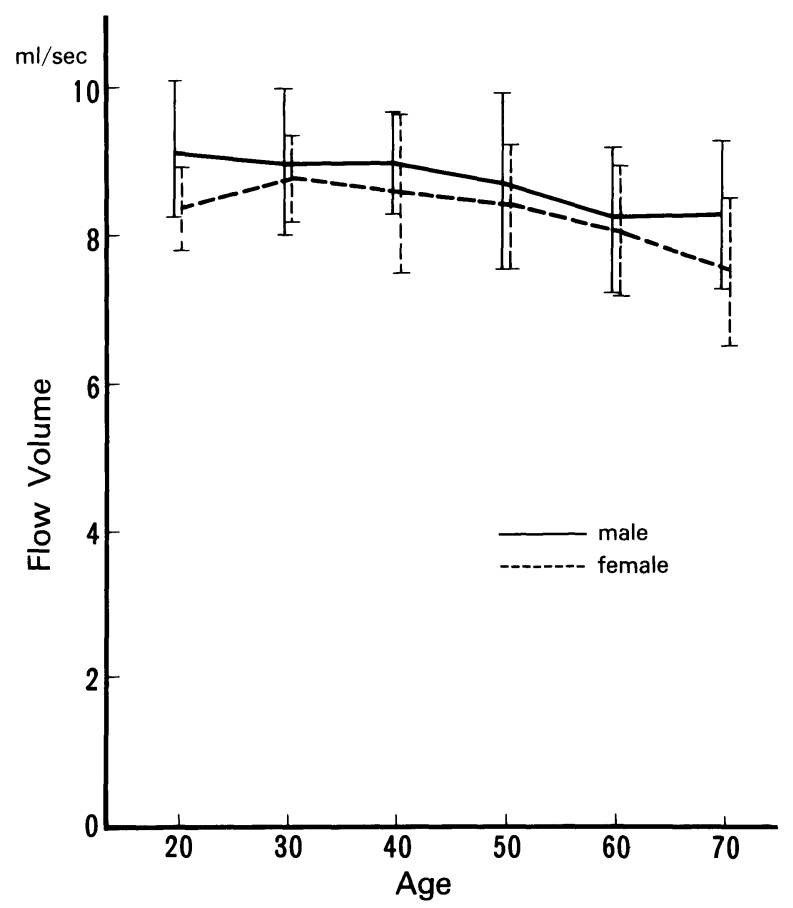

Fig. 10 Difference of common carotid blood flow volume between men and women. 
Table 1 Previous reports of common carotid blood flow volume ( $95 \%$ confidence interval) in healthy subjects measured by QFM.

\begin{tabular}{lrccc}
\hline \multicolumn{2}{c}{ Author } & \multicolumn{1}{c}{$\mathrm{n}$} & \multicolumn{1}{c}{ age } & flow volume $(\mathrm{m} l / \mathrm{sec})$ \\
\hline \multicolumn{2}{c}{ Fujishiro (1982) } & 140 & $10-79$ & $6.9-10.4$ \\
Uematsu (1983) & 120 & $21-60$ & $6.5-8.7$ \\
Obara $\quad(1984)$ & 140 & $10-79$ & $6.9-10.4$ \\
Müller $\quad(1984)$ & 100 & $16-65$ & $7.1-8.6$ \\
Sugihara (1985) & 60 & $21-69$ & $6.8-9.9$ \\
Sawai $\quad(1987)$ & 108 & $30-79$ & $6.6-11.4$ \\
\hline
\end{tabular}

差は認められていない.

Fig.10 は, 前述と同一症例, 各年代 25 例左右 50 側に ついて男女差を見たものであるが，男性が平均 $+5.8 \%$ の高值を示している. Müllerも，女性より男性で+5\% 多いと報告している ${ }^{677)}$. 体格の差が強く関与していると 考えられる。

健常成人の総頸動脈血流量につき平均値, 標準偏差, 症例数から $95 \%$ の信頼区間を算出すると 7.73 から 9 . 23 となる. Table 1 はこれまでの報告について同様に信 頼区間を算出しまとめたものであるが下限值は $6.5 \sim 7$. $1 \mathrm{~m} \ell / \mathrm{s}$ ，上限值は 8.6 11.4 ml/s で，下限值がやや低め であるがほぼ一致している6(8)10111)13114).

\section{4-2 左右差}

前述のように多数例の平均としては有意な左右差は認 めないが，各個人における左右差は主に Willis 動脈輪の 解剖学的バリエーションにより生ずると考えられる.

Müller は, 16 歳から 65 歳までの健常者 100 例につき 左右合計の $20 \%$ 以上の左右差を示したものは 1 例のみ で，診断パラメータとして左右合計值の $20 \%$ が役立ち, これ以上のものは流体力学的に有意な病変の存在が示唆 されるとしている6 ${ }^{6}$.

\section{5. 異常計測値}

\section{5-1 総颉動脈血流量の増大}

QFM では計測値は 1 秒間の血流量として算出される ため，心拍数には直接依存しない。しかし，精神的緊張 や興奮で度々増大をみる。このため, 計測前の安静を守 らせても初回計測では高值に出ることがあるため注意を 要する. 甲状腺機能六進症患者では血流量の増大を見る. これは心機能六進と末梢循環抵抗の減少に由来し，主に 外頸動脈血流が増大するためでホルモンレベルより BMR と良い相関を示す ${ }^{15)}$. 貧血でも増大が考えられる.
椎骨脳底動脈循環不全の患者では，Willis 動脈輪を介 した補償により総頸動脈血流量は増大することがある ${ }^{11)}$. 他に頸動脈系の動・静脈瘻，血管腫などでも有意な増大 をみることが多い16).

\section{5-2 過大計測}

総頸動脈には内頸静脈が近接する。このため血管内全 域からの血流信号検出を必要とする血流量計測に際して は，時に分離困難な事がある．故に本装置では計測の簡 便さを重視し，通常頸動脈血流には逆流成分が無いこと に着目，順方向指示型にしてある.

このため高度の大動脈弁閉鎖不全症で拡張期に逆流が あると，その間血流はゼロ表示し，平均流量は実際より 多く計測される。大動脈炎症候群などの患者で計測部近 傍に高度狭窄があり，乱流とくに渦流が存在すると過大 計測に成り易い。

また心拍数の算出が加算波形中の最短 $\mathrm{R}-\mathrm{R}$ から行な われ，血流量計算 $(\mathrm{m} \ell / \mathrm{s})$ がなされるため心房細動例では 過大計測になることが多い。これは洞性不整脈でも起こ り得る。

以上のことは計測に際していつも念頭にいれておく必 要がある.

\section{5-3＼cjkstart総頸動脈血流量の低下}

全身的に循環動態が低下した状態では総頸動脈におい ても影響を受ける．しかし，そのような原因無くして血 流量の低下を見た場合は頸・脳動脈系における奇形や動 脈硬化による狭窄や閉塞病変の存在が疑われる。

なお，脳血管障害急性期には脳圧方進があると血流量 は低下する．またクモ膜下出血後の血管攣縮でも総頸動 脈血流量は低下すると報告されている。

\section{6. 敇々状態下における䌊頸動脈血流量の生理的変動}

\section{6-1 起立時の変化}

25 歳から 43 歳までの健常男性 14 人につきチルトテ ーブルを用い起立直後の総頸動脈血流を計測した結果を 示す.

Fig.11 のごとく, うち 7 例は起立前後で血流量はほと んど変化を示さず (平均-3.3\%), 他の 7 例は著明な減少 を示している(平均一 $22.2 \%$ )。 なお，起立時の血圧低下 は全例に损いて $15 \mathrm{mmHg}$ と正常反応で両群間にも有意 差は無い.しかし心拍数の増加率は前者 $+19 \%$ ，後者十 $30 \%$ で有意差を認め, 健常人での起立直後の総頸動脈血 流量の保持には神経反射機構の優劣が強く関与しており， 心拍数の増加により血流量が維持されると思われる. 


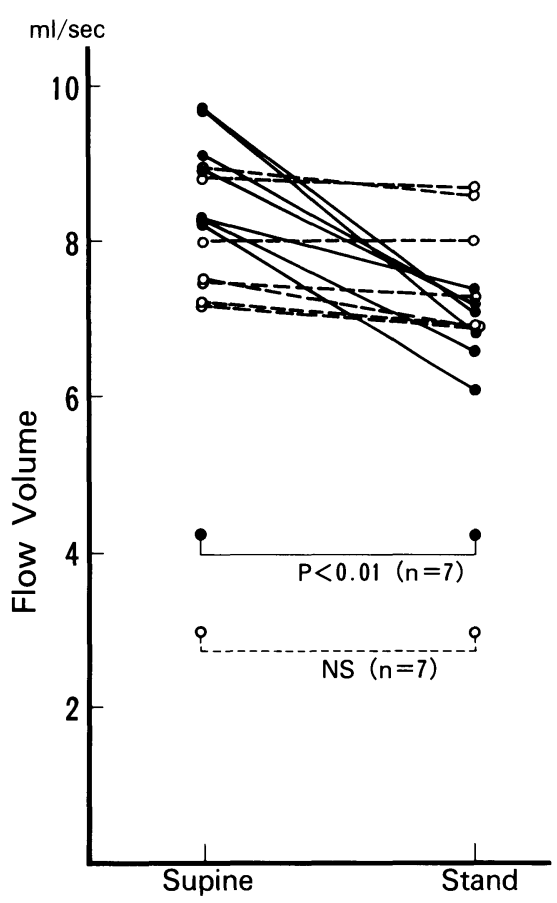

Fig. 11 Fast changes of common carotid blood flow volume from supine position to stand.

\section{6-2 血圧の影響}

正常な脳では自動調節機構（autoregulation）が存在 し，平均血圧として約 50 から $150 \mathrm{mmHg}$ の範囲の血圧 変動に対しては脳血流は一定に保持されるとされている. 筆者らの, 高血圧患者 7 例についての経時的変化の検討 でもFig.12のごとく regression line の平均増加係数 は+0.0146で, 平均血圧 74 から $168 \mathrm{mmHg}$ の範囲では 有意な上昇は認められていない，高血圧患者においては 前記の自動調節機構の域值が上方に偏位すると言われて おり，総頸動脈血流でも強い影響を受けていることを証 明している.これは逆に総頸動脈血流でも,かなりの程度 に脳循環動態の評価が可能であることを示す結果である.

\section{6-3 睡眠}

増田らはQFM を用いて睡眠中の総頸動脈血流量を測 定し報告している。これによると血流量は覚醒時, REM 睡眠, NREM 睡眠の順に低下, 後 2 者ではそれぞれ覚醒 時に比べ約 $10 \%, 20 \%$ の低值を示している.しかし, こ の REM 睡眠中の血流はその時期によりかなり異なる特 性を示し，また NREM 睡眠中は sleep stage に比例し， 睡眠が深くなれば血流量が減少するとしている17).

${ }^{133} \mathrm{Xe}$ gas inhalation methodによる局所脳血流量 (rCBF) の測定では, rCBF は REM 睡眠時には覚醒時 より増大, NREM 睡眠時には低下すると報告されてお

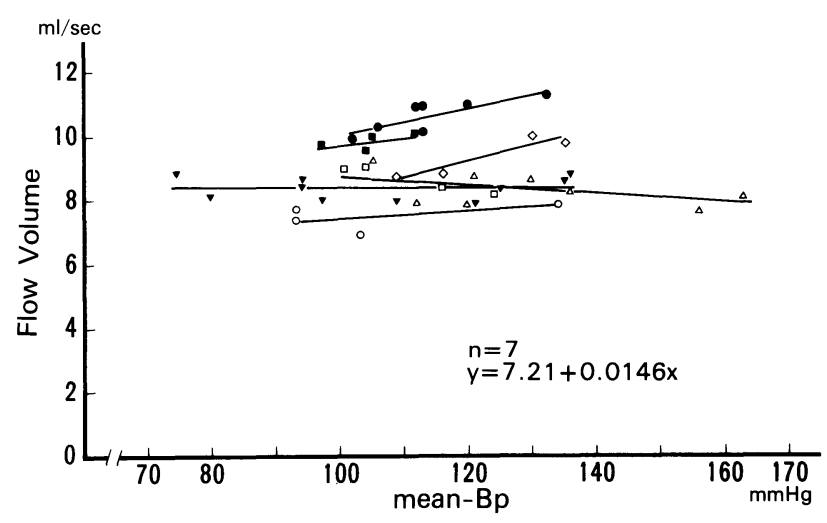

Fig. 12 Influence of blood pressure fluctuation on common carotid blood flow volume.

り ${ }^{18) 19)}$, これについては内·外頸動脈血流配分の変化, 椎 骨・脳底動脈系の関与等を挙げ考察している.

\section{6-4 運動}

運動時の脳循環についてはその測定法の困難さから報 告も少なく, 見解も統一していない. 池田らは, 健常青 年 5 例について坐位 40 度 (上体の傾斜角度) で自転車工 ルゴメータ負荷を行ない総頸動脈血流量の変化を検討し ている，負荷量は $1.5 \mathrm{kp} \cdot 50 \mathrm{rpm}$ の軽負荷である.これ によると総頸動脈血流量は全例で運動中低下を示し, 回 復直後に rebound を示し, 安静時血流レベルより高い值 を示したと報告している ${ }^{20)}$. しかし運動による血流量の 変化には脳循環の自動調節機構が強く関与しており, 負 荷強度によりその反応性が異なることも考えられ, 詳細 は今後の研究に待たれる.

以上健常人に打ける総頸動脈血流量についてその一部 を述べたが，生理的さらには病態についてもまだ解明す べき点が多く残されている.

$\mathrm{QFM}$ 装置がその特徵を充分理解され, 各種臨床さら に研究に広く貢献することを期待する。

\section{文 献}

1) 古幡 博, 菅野亮一, 古平国泰ほか。超音波血流量測定装置 の開発. 医用電子と生体工学 $1978 ； 16$ (特別号) : 334 .

2 ) 古平国泰, 古幡 博, 下地悦郎ほ力。非観血的脳血流量測定 装置の開発. (財) 医療技術研究開発財団. 昭和 53 年度研究 開発報告書. $1979: 95$.

3) Yoshimura S, Kodaira K, Fujishiro K, Furuhata H. A newly developed non-invasive technique for quantitative measurement of blood flow-with special reference to the measurement of carotid arterial blood flow. Jikeikai Med J $1981 ; 28: 241-56$.

4) Fujishiro K, Yoshimura S. Development of ultrasonic 
quantitative blood flow measuremnt system (QFM). Jikeikai Med J $1982 ; 29: 57-74$.

5 ) 吉村正蔵, 古幡 博, 鈴木直樹, 古平国泰, 広田秀美. 内頸· 外頸動脈および椎骨動脈血流量の超音波による無侵襲的定量 測定法の開発. 脈管学 $1982 ； 22: 191-8$.

6 ) Müller H R, Radue E W, Saia A, Pallotti C, Buser M. Carotid blood flow measurement by means of ultrasonic techniques : Limitations and clinical use. In : Harfmann, Hoyer, eds. Cerebral blood flow and metabolism measurement. Berlin : Springer-Verlag, 1985 : 571-92.

7) Müller H R, Radue E W,Pallotti C, Gratzl O. Common carotid CW Doppler flow measurement in neurovasculer surgery. In : Kurjak A, Kossoff G, eds. Recent Adv Ultrasound Diagn 4. Elsevier Science Pub, 1984: 17-36.

8 ) Uematsu S, Yang A, Preziosi T J, Kouba R, Toung T J K. Measurement of carotid blood flow in man and its clinical application. Stroke $1983 ; 14: 256-66$.

9 ) Uematsu S. Determination of volume of arterial blood flow by an ultrasonic device. J Clin Ultrasound 1981 ; 9:209-16.

10) Fujishiro K, Yoshimura S. Haemodynamic changes in carotid blood flow with age. Jikeikai Med J $1982 ; 29$ : 125-38.

11) Obara K,Kodaira K. Non-invasive quantitative assessment of carotid and cerebral arteriosclerosis-by ultrasonic quantitative blood flow measurement system and its clinical application. Jikeikai Med J $1984 ; 31: 93-111$.
12) Yoshimura S, Kodaira K, Fujishiro K, Furuhata H. Noninvasive and quantitative measurement of commom carotid blood flow volume and estimation of cerebral atherosclerosis using ultrasonic quantitative flow measurement system (QFM). Angeiologie $1984 ; 36(2): 53-66$.

13）杉原 浩. 超音波ドプラ法 $(\mathrm{QFM})$ による脳梗塞例の総頸動 脈血流量の検討。日本臨床生理学会雑誌 $1985 ; 15 ： 405-16$.

14）澤井冬樹. 脳萎縮と脳循環（第 2 報）一加柃と総頸動脈血流 動態 奈医誌 $1987 ； 38 ： 980-9$.

15）伊藤克朗．超音波定量的血流量測定装置による甲状腺機能立 進症の頸・脳動脈系循環動態の検討．慈恵医大誌 1985； $100: 1249-60$.

16）吉村正蔵，古平国泰，小原一夫，藤代健太郎，清水久盛，古 幡 博. 無侵襲性診断法. 臨床と研究 $1982 ； 59 ： 1068-78$.

17）増田 允，長谷川豪志，池田道明，内野鉄司。睡眠時の総頸 動脈血流. 脳循環の適応機構の解析一七トを対象にして. 慈 恵医大昭和 55 年, 56 年度学内共同研究報告書 1983：1-6.

18) Townsend R E, Prinz P N,Obrist W D. Human cerebral blood flow during sleep and waking. J Appl Physiol 1973; $35: 620-5$

19) Juge O, Meyer J S, Sakai F, Yamaguchi F, Yamamoto M, Shaw T. Critical appraisal of cerebral blood flow measured from brain stem and cerebellar regions after ${ }^{133} \mathrm{Xe}$ inhalation in humans. Stroke $1979 ; 10: 428-37$.

20）池田道明，増田 允. 軽運動時の総頸動脈血流量. 脳循環の 適応機構の解析一七トを対象にして. 慈恵医大昭和 55,56 年 度学内共同研究報告書 1983:7-11. 